\title{
The relationship between mTOR signalling pathway and recombinant antibody productivity in $\mathrm{CHO}$ cell lines
}

\author{
Raihana Edros, Susan McDonnell and Mohamed Al-Rubeai
}

\begin{abstract}
Background: High recombinant protein productivity in mammalian cell lines is often associated with phenotypic changes in protein content, energy metabolism, and cell growth, but the key determinants that regulate productivity are still not clearly understood. The mammalian target of rapamycin (mTOR) signalling pathway has emerged as a central regulator for many cellular processes including cell growth, apoptosis, metabolism, and protein synthesis. This role of this pathway changes in response to diverse environmental cues and allows the upstream proteins that respond directly to extracellular signals (such as nutrient availability, energy status, and physical stresses) to communicate with downstream effectors which, in turn, regulate various essential cellular processes.
\end{abstract}

Results: In this study, we have performed a transcriptomic analysis using a pathway-focused polymerase chain reaction $(\mathrm{PCR})$ array to compare the expression of 84 target genes related to the mTOR signalling in two recombinant $\mathrm{CHO}$ cell lines with a 17.4-fold difference in specific monoclonal antibody productivity $\left(q_{p}\right)$. Eight differentially expressed genes that exhibited more than a 1.5-fold change were identified. Pik3cd (encoding the Class 1A catalytic subunit of phosphatidylinositol 3-kinase [PI3K]) was the most differentially expressed gene having a 71.3-fold higher level of expression in the high producer cell line than in the low producer. The difference in the gene's transcription levels was confirmed at the protein level by examining expression of p1108.

Conclusion: Expression of $110 \delta$ correlated with specific productivity $\left(q_{p}\right)$ across six different $\mathrm{CHO}$ cell lines, with a range of expression levels from 3 to $51 \mathrm{pg} / \mathrm{cell} /$ day, suggesting that p110 may be a key factor in regulating productivity in recombinant cell lines.

Keywords: $\mathrm{CHO}, \mathrm{mTOR}$, Monoclonal antibody, Phosphotidylinositol 3-kinase, Cell engineering

\section{Background}

The production of biopharmaceutical products is one of the fastest growing areas in the pharmaceutical industry with sales of $\$ 99$ billion in 2010 [1,2]. Many of these biopharmaceutical products are used to treat critical diseases, like hepatitis, cancer, heart disease, hemophilia, rheumatoid arthritis, and diabetes. Monoclonal antibodies (mAbs) currently constitute more than $30 \%$ of total biopharmaceuticals and the portfolio of products is expected to grow between $7-15 \%$ per annum in the coming years. Whilst the future does looks bright for this sector, the emergence

\footnotetext{
* Correspondence: m.al-rubeai@ucd.ie

School of Chemical and Bioprocess Engineering and Conway Institute of Biomolecular and Biomedical Research, University College Dublin, Dublin, Ireland
}

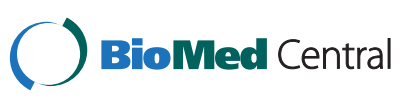

(c) 2014 Edros et al.; licensee BioMed Central Ltd. This is an Open Access article distributed under the terms of the Creative Commons Attribution License (http://creativecommons.org/licenses/by/2.0), which permits unrestricted use, distribution, and reproduction in any medium, provided the original work is properly credited. The Creative Commons Public Domain Dedication waiver (http://creativecommons.org/publicdomain/zero/1.0/) applies to the data made available in this article, unless otherwise stated. of biosimilar competition is ensuring that manufacturers of these products are continuously seeking methods of increasing productivity of cell culture processes to maximise yields.

Numerous attempts have been made to generate cell lines that can produce large amounts of recombinant products. Among the cell lines available for $\mathrm{mAb}$ production are myeloma, hybridoma, and Chinese hamster ovary $(\mathrm{CHO})$ cell lines $[3,4]$. The use of $\mathrm{CHO}$ cells in large-scale production is common [3,5-7] because of their ability to express high recombinant protein levels $[8,9]$, grow to high cell densities [10-13], and to grow in serum-free suspension culture [6,14-16]. CHO cells are also suitable for use with expression systems, such as

ras otherwise stated. 
dihydrofolate reductase (DHFR) and glutamine synthetase (GS) [17-19].

High productivity is usually accompanied by slower growth rates [20-25], and generating high-producing cell lines with high growth rates should be advantageous to further improve mAb production. However, maintaining cell-specific productivity at high growth rates is challenging because both processes require high energy. Glutamine and glucose are often consumed in the synthesis of precursors for recombinant proteins rather than in cell proliferation [26], which eventually leads to growth repression.

The correlation between cell volume (size) and productivity has been clearly demonstrated [27] and is reflected in the phenotypic changes in protein content and cell biomass $[13,28,29]$. This increase in protein content may lead to an increase in cell size $[25,29,30]$. The integration of both protein synthesis and cell proliferation in response to diverse environmental cues has been reported to be regulated by a signalling pathway known as the mammalian target of rapamycin (mTOR) signalling pathway [31,32].

As shown in Figure 1, upon receiving signals from growth factors and hormones, mTOR is activated by Akt/P13K signalling [33,34]. P13K catalyses the formation of phosphoinositides-3-phosphate (PIP3) from phosphoinositides-2-phosphate (PIP2), which then activates a protein kinase known as Akt [35]. The activated mTOR initiates protein synthesis via two principal pathways; firstly through the inhibition of eukaryotic initiation factor $4 \mathrm{E}$ binding protein (4EBP1) and secondly through the activation of ribosomal protein S6 kinase (S6K) [36,37]. These downstream effectors activate protein synthesis by activating translation initiation and elongation factors, including eIF4E, eIF4B, S6, and eEF2 [32,38].

In addition to growth factors and hormones, mTOR also receives signals from phosphatidic acid (PA) [39] and amino acids $[38,40,41]$. In the presence of serum, protein kinase $\mathrm{C}$ (PKC) is activated, and it sequentially activates phospholipase D (PLD) which is responsible for converting PA to phosphatidylcholine (PC) [39]. In contrast, the activation of mTOR by amino acids is unclear [32]. It was reported to be regulated by the Ras protein [41] and/or intracellular amino acids [38,42]. Moreover, adenosine monophosphate kinase (AMPK) can also precisely modulate mTOR activity based on the adenosine monophosphate (AMP) to adenosine triphosphate (ATP) ratio [43]. In the presence of high intracellular ATP levels, AMPK can be deactivated, leading to an increase in protein synthesis $[44,45]$.

A recent study highlighted the role of mTOR in improving viability, cell growth, antibody production, and robustness of the $\mathrm{CHO}$ cell line [46]. However, the mechanism underlying these improvements has not yet been elucidated. We believe that using a transcriptomic approach, such as the pathway-focused polymerase chain reaction (PCR) array, which has proven to be useful in a similar study [47], we can elucidate the connections between mTOR, cell growth, and productivity. Thus, this study initially employed two recombinant $\mathrm{CHO}$ cell lines with a 17.4-fold difference in specific productivity to

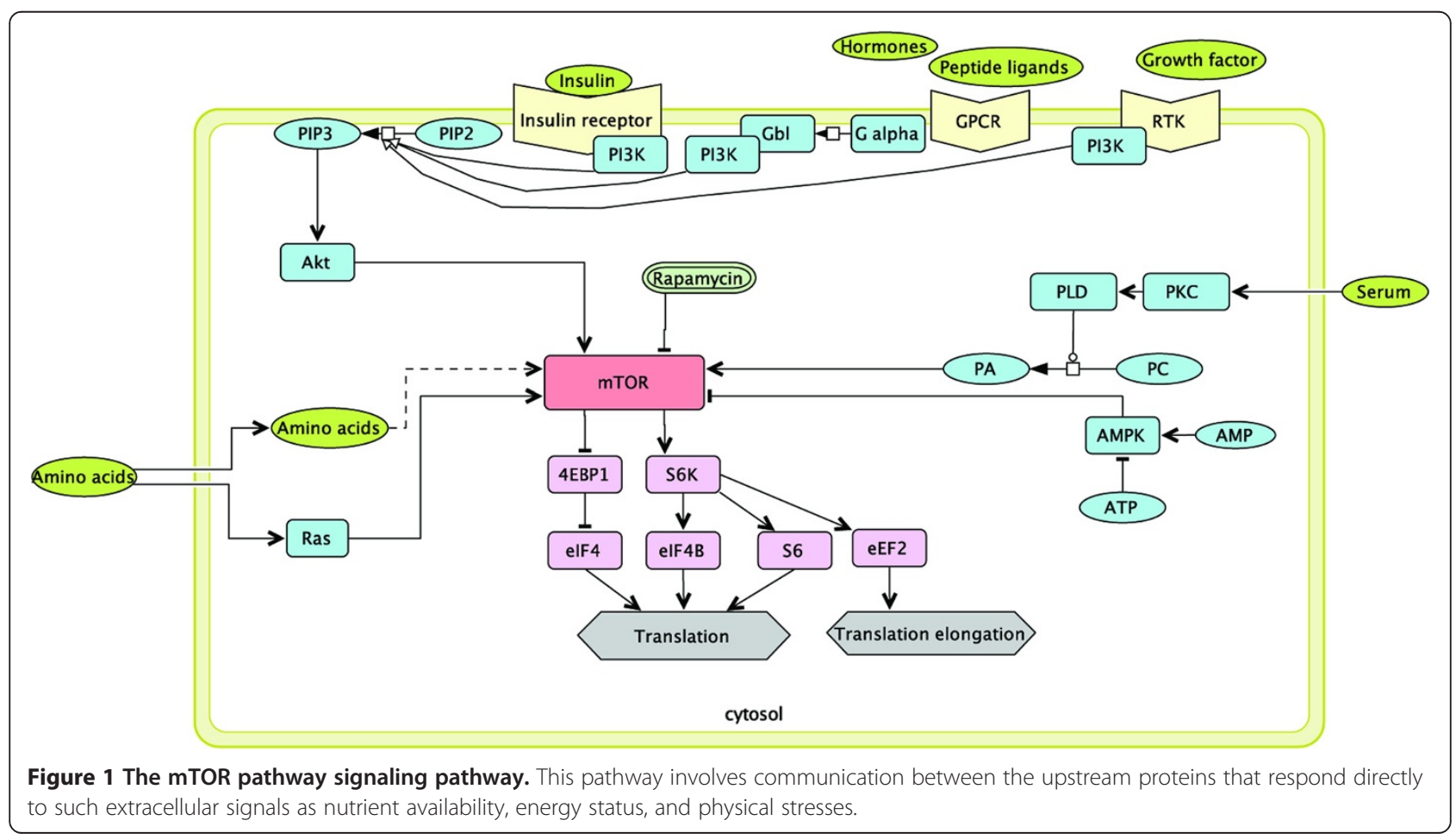


study the differential expressions of genes related to the mTOR signaling pathway. High productivity has been associated partly with enhanced translation mechanisms [48]. We therefore expected to see upregulation of genes encoding mTOR upstream regulators such as, Akt [49,50], PI3K [51,52], PLD [39,53], and Ras-related GTP binding proteins (RagC) [41,54,55], as well as downstream effectors involved in translation mechanisms such as S6 and S6K [56-59]. Since high gene expression does not necessarily mean that the corresponding protein is also highly upregulated in the cell, we decided to perform Western blot analysis to confirm that the selected potential marker $\mathrm{p} 110 \delta$ was expressed in increasing amount in a panel of $6 \mathrm{CHO}$ cell lines with varying levels of productivity.

\section{Methods}

\section{Cell lines and maintenance}

This study employed a panel of six GS-CHO cell lines (referred to as CL38, CL47, CL76, CL150, CL160 and CL164) producing cB72.3 IgG4 monoclonal antibody with varying levels of productivity. The cell lines were kindly provided by Lonza Biologics (Slough, UK). The cell lines were generated by transfection of the suspension-variant derivatives CHO-K1 (CHOK1SV) with the glutamine synthetase (GS) expression vector pcB72.3 containing light chain (LC) and heavy chain (HC) cDNA, each driven by the hCMV-MIE promoter [60,61]. Cells were maintained in $\mathrm{CD}-\mathrm{CHO}$ medium supplemented with $25 \mu \mathrm{M}$ MSX. Using three biological replicates, our experiments were conducted in $125 \mathrm{ml}$ shake flasks (SCHOTT Inc., Elmsford, USA) at $37^{\circ} \mathrm{C}$ and $140 \mathrm{rpm}$ agitation.

The six cell lines were numbered in descending order according to their specific productivity, with [1] referring to the most productive cell line and [6] referring to the least productive cell line. These cell lines were thus referred to as CL47[1], CL76[2], CL150[3], CL164[4], CL38 [5] and CL160[6] throughout this study . Based on specific productivity, CL47[1] was categorised as the high producer; CL76[2], CL150[3], CL164 [4], and CL38[5], as medium producers; and CL160[6], as the low producer.

\section{Flow cytometric analysis of cell number and viability}

Cell suspensions $(490 \mu \mathrm{l})$ were removed from flasks and placed in a flow cytometry tube and $10 \mu \mathrm{l}$ propidium iodide (PI) solution added from the stock solution $(0.5 \mu \mathrm{g} / \mathrm{ml})$. Samples were mixed by gentle shaking and analysed immediately for cell numbers and viability, using Cell Lab Quanta SC flow cytometry (Beckman Coulter Inc., CA, USA) equipped with an argon laser $(488 \mathrm{~nm})$. Red fluorescence (PI) was collected using a $635 \mathrm{~nm}$ band pass filter. Analysis was undertaken by loading an appropriate protocol for the acquired parameters: electronic volume (EV), log side scatter (SS), and
PI integral; 10000 observations were collected for analysis. The evaluation of cell number was achieved by gating areas in the EV versus log SS dot plot in which living cells and dead cells appear.

We used the following equation to calculate the specific growth rate, $\mu$ :

$$
\mu=\frac{\left(\ln X_{V_{1}}-\ln X_{V_{0}}\right)}{t_{1}-t_{0}}
$$

Where $X_{V_{1}}$ and $X_{V_{0}}$ symbolise the viable cell density at time points $t_{1}$ and $t_{0}$, respectively.

\section{Determination of antibody concentration}

Enzyme-linked immunosorbent assay (ELISA) was used to determine the concentration of mAb secreted by the cell lines, as described previously [30]. The antibody was sandwiched between monoclonal anti-human IgG Fc (SigmaAldrich, St. Louis, USA) and anti-human kappa light chain horseradish peroxidase (HRP) conjugates (Sigma-Aldrich). The concentration of antibody in the samples was determined using o-phenylenediamine (OPD; Sigma-Aldrich) as a substrate, and the specific productivity, $q_{p}$, was calculated using the following equation:

$$
q_{p}=\frac{[M A b]_{1}-[M A b]_{2}}{C V C T}
$$

where $[\mathrm{MAb}]$ represents the antibody concentration at a particular time, while cumulative viable cell time (CVCT) is the sum of the individual areas given by

$$
C V C T=\sum\left(\left(\frac{x_{1}+x_{0}}{2}\right) \times\left(t_{1}-t_{0}\right)\right)
$$

Where $x_{0}$ represents the cell number at the particular time $t_{0}$ and $x_{1}$ represents the cell number at the elapsed time $t_{1}$.

\section{Quantitative real-time PCR (qRT-PCR) analysis}

$3 \times 10^{6}$ cells were removed from the flask at the midexponential phase (day three of the batch culture), centrifuged, and washed twice by PBS. The sample was treated with RNAlater and stored at $-80^{\circ} \mathrm{C}$ until analysis, at which point it was centrifuged to remove the RNAlater stabilization reagent. RNA isolation was carried out using the RNeasy Mini Kit (QIAGEN, Valencia, CA, USA) according to the manufacturer's instructions. The concentration of RNA was determined using a NanoDrop ND-1000 UV-vis Spectrophotometer (Nanodrop Technologies, Wilmington, DE, USA), and the integrity of RNA was checked using an Agilent Bioanalyzer (Santa Clara, CA, USA).

The expression levels of mTOR-related genes were quantified using a mouse-mTOR-pathway-focused qRT-PCR array from SA Biosciences (Frederick, Maryland, USA). 
The DNA elimination treatment was carried out, and complementary DNA (cDNA) was synthesized from the RNA samples, using the $\mathrm{RT}^{2}$ First Strand Kit (SA Biosciences) according to the manufacturer's instructions. The cDNA samples were mixed with $\mathrm{RT}^{2}$ SYBR Green/ROX qRTPCR Master Mix reagents (SA Biosciences) according to the manufacturer's instructions, and the qRT-PCR was performed on these samples using ABI Prism 7500 FAST sequence detection system (Applied Biosystems, Carlsbad, CA, USA). The $C_{t}$ values obtained from the qRT-PCR analysis were normalised to five housekeeping genes (beta glucuronidase [Gusb], hypoxanthine quinine phosphoribosyl transferase 1 [Hprt1], heat shock protein 90 alpha [Hsp90ab1], glyceraldehyde-3-phosphate dehydrogenase [Gapdh], and beta actin [Actb]). The normalization was calculated by using the $2^{-\triangle \Delta C T}$ method, as previously described [62].

\section{Total protein content}

The total protein content was determined using the QuantiPro BCA Assay Kit (Sigma-Aldrich). $3 \times 10^{6}$ cells were removed from the flask, centrifuged and then washed once with sterile-filtered PBS. The cells were then centrifuged at $500 \mathrm{~g}$ for five minutes and supernatant removed. A mixture of CelLytic M Cell Lysis Reagent (Sigma-Aldrich) and a protease inhibitor cocktail (Sigma-Aldrich) was added to disrupt the cells. The samples were mixed by vortexing for one minute, centrifuged at $15000 \mathrm{~g}$ for 15 minutes at $4^{\circ} \mathrm{C}$. The supernatant was transferred to a new microcentrifuge tube and stored at $-20^{\circ} \mathrm{C}$ until analysis.

\section{Western blot analysis}

For western blot analysis, $20 \mu \mathrm{g}$ of total protein was mixed in $2 \times$ Laemmli buffer (Sigma-Aldrich) and denatured at $95^{\circ} \mathrm{C}$. The samples were then subjected to electrophoresis on an $8 \%$ polyacrylamide gel (Thermo Scientific, Waltham, MA, USA) using a Mini Protean 3 electrophoresis system (Bio-Rad Laboratories, Waltham, MA, USA) for 90 minutes. The proteins were transferred electrophoretically to a PVDF membrane (Millipore Corporation, Cheshire, NH, USA) overnight. The membrane was blocked in non-fat milk powder in PBST followed by an overnight incubation with an anti-mouse p110 $\delta$ PI3K antibody (Santa Cruz Biotechnology, Santa Crus, CA, USA). The membrane was probed with a secondary antibody solution containing anti-goat IgG peroxidase conjugates prior to detection using a SuperSignal West Pico kit (Thermo Scientific) according to the manufacturer's instructions. Upon reaction, the membrane was exposed, developed, and fixed on a film. The band intensity was measured by the AlphaDigiDoc RT2 gel documentation system software (Alpha Innotech Corporation, CA, USA).

\section{Results}

Comparing the growth and productivity of the high and low producers

The C47 [1] and CL160 [6] lines, which expressed the recombinant chimeric IgG4 mAb, were grown in batch cultures in three biological replicates. The cell numbers and antibody concentrations, determined by flow cytometric analysis and ELISA, respectively, were determined routinely throughout the culture duration until the cells reached the death phase. The cell growth rates and cumulative viable cell time (CVCT) were determined throughout the exponential phase, from day one to day five of batch culture as shown in Table 1 . The viable cell density, viability, and antibody concentration profiles are shown in Figure 2. Following a normal growth curve, CL160[6] outperformed CL47[1] in terms of growth, as demonstrated by the calculated CVCT and growth rate $(\mu)$ of $329.66 \pm$ $17.99\left(10^{9}\right.$ cell.h/L) and $0.67 \pm 0.01\left(\right.$ day $\left.^{-1}\right)$ in CL160[6], compared to $244.48 \pm 4.58\left(10^{9}\right.$ cell.h/L $)$ and $0.63 \pm 0.01$ $\left(\right.$ day $\left.^{-1}\right)$ in CL47[1], respectively. However, CL47 [1] sustained high viability towards the decline phase (day 8), while the viability of CL160[6], on the contrary, started to decrease sharply on day seven. In CL 47[1], the specific productivity and total antibody concentration, as indicated in Table 1, were 17.4- and 11-fold higher than CL160[6], respectively.

\section{Differential mTOR-related gene expression between high and low producers}

We hypothesized that the differences in CL47 [1] and CL160[6] productivity levels are a consequence of the diverse mechanisms of cellular functions that are controlled by mTOR. Using a commercially available pathway-focused PCR array, the expression of 84 genes related to the mTOR signalling pathway were screened in the template cDNA which was prepared from the samples collected at the mid-exponential phase (day three of the batch culture). Figure 3 demonstrates the relative expression of the mTOR-related genes exhibited by the high producer (CL47[1], treated) in comparison to the low producer (CL160[6], control). Student's t-tests were conducted to determine the significance of the gene expression changes. Out of the 84 mTOR-related genes in this

Table 1 The culture characteristics and cell productivity of high producer (CL47[1]) and low producer (160[6]) cell lines during batch culture

\begin{tabular}{lll}
\hline & 47[1] & 160[6] \\
\hline CVCT $\left(10^{9}\right.$ cell.hr/L) & $244.48 \pm 4.58$ & $329.66 \pm 17.99$ \\
Antibody concentration $(\mu \mathrm{g} / \mathrm{ml})$ & $575.24 \pm 137.55$ & $52.08 \pm 0.77$ \\
Growth rate $\left(\right.$ day $\left.^{-1}\right)$ & $0.63 \pm 0.01$ & $0.67 \pm 0.01$ \\
$q_{p}(\mathrm{pg} /$ cell/day;pcd) & $50.54 \pm 3.18$ & $2.91 \pm 1.45$ \\
\hline
\end{tabular}

The symbol " \pm " represents the standard deviation calculated between the three biological replicates. 


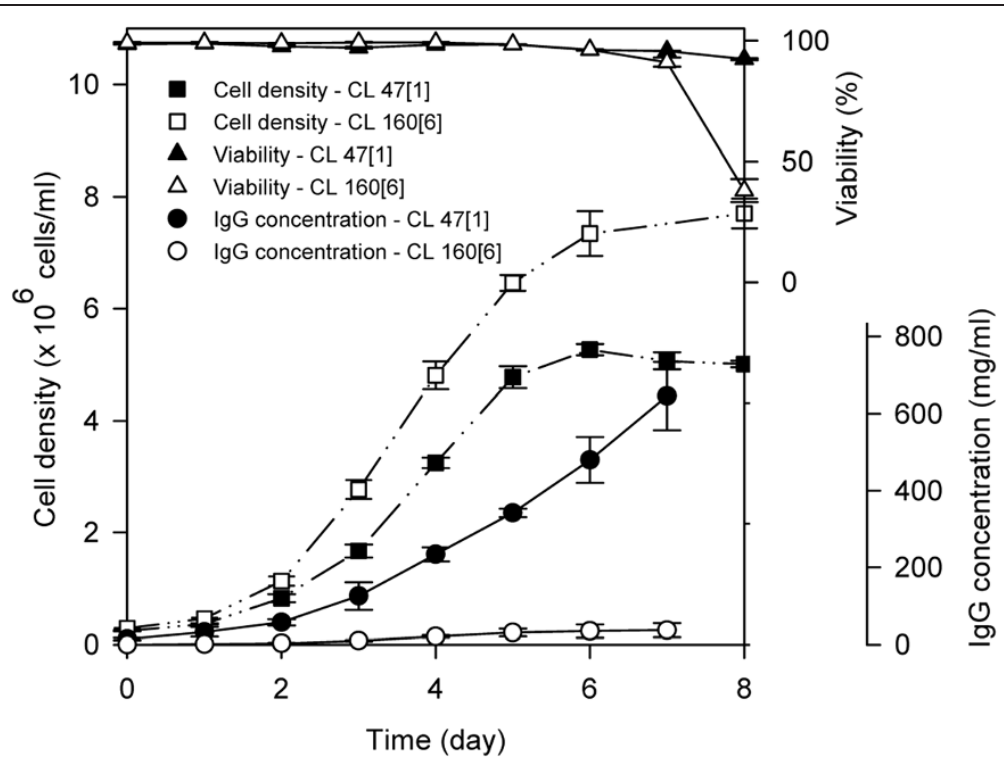

Figure 2 Viable cell density, viability, and antibody concentration profiles of high producer (CL47[1]) and low producer (CL160[6]) cells lines during batch culture. Error bars symbolize the standard deviation as calculated between three biological replicates.

array, eight genes expressed at least a 1.5 -fold difference (Pik3cd, Pik3cg, Pld1, Rragc, Ins2, Telo2, Rps6 and Prkab1), with a corresponding statistical significance $(P$-value $<0.05)$ between the high and low producers (Figure 4). These genes were all upregulated.

\section{Expression of genes in mTOR signalling pathway}

The list of mTOR-related genes with significantly altered expression in CL47[1] relative to CL160[6] is presented in Table 2. Three differentially expressed genes involved in insulin signalling were upregulated. The most upregulated gene, $p i k 3 c d$ at 71.3 -fold (P-value $<0.05$ ), encodes the catalytic subunit of the delta polypeptide p110 $\delta$. The gene encoding a p110 $\delta$ sibling, the gamma polypeptide (p110 $\gamma$ ) subunit, was also significantly expressed but to a lesser extent $(6.6$-fold; P-value $<0.05)$. The p110 $\delta$ and $\mathrm{p} 110 \mathrm{\gamma}$ subunits are classified as Class $1 \mathrm{~A}$ and $1 \mathrm{~B}$, respectively and both receive signals from insulin and various types of growth factors $[51,63,64]$. Another gene related to insulin signalling that was also significantly expressed was insulin 2 (Ins2), with a 3.06-fold change (P-value $<0.05)$.

Ras-related GTP-binding protein C (Rragc) and phospholipase D1 (Pld1) were also expressed significantly, with fold changes of 3.08 and 4.63 , respectively (P-value $<0.05$ ). Unlike RagC, which has a response specific to amino acid availability $[41,54,55]$, PLD1 is activated by mitogens such as serum [39]. Moreover, the expression of the regulatory

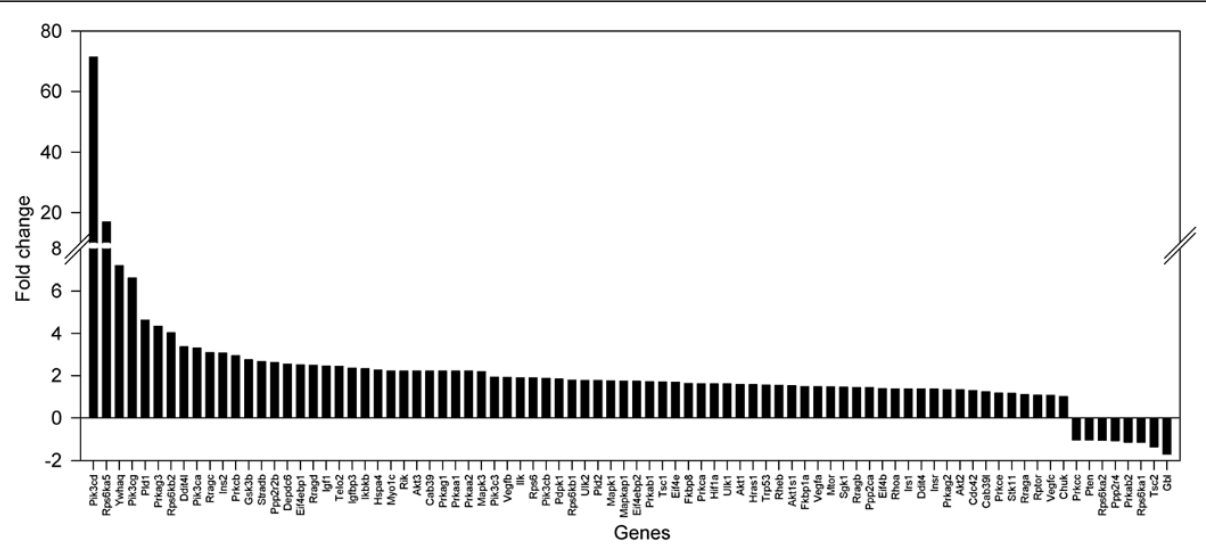

Figure 3 The fold changes of mTOR-related gene expressions of GS-CHO cell lines at the mid-exponential phase of batch culture.

Values were calculated based on a relative quantification made between high producer (CL47[1]) and low producer (160[6];Control) lines by using the $2^{-\triangle \Delta C T}$ method. 


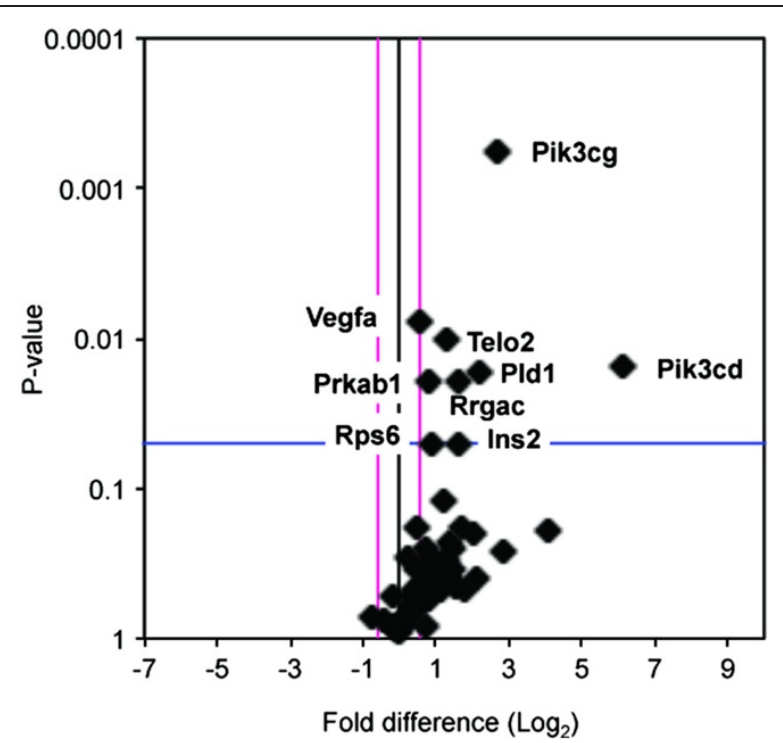

Figure 4 The $\log _{2}$ fold changes in gene expression between high producer (CL47[1]) and low producer (160[6]) lines against t-test P-values. Vertical line represents the threshold of fold changes (i.e., 1.5); horizontal line represents the significant difference of t-test P-values (i.e., 0.05). Significantly expressed genes $(P$-values $<0.05)$ are tabulated in Table 2.

gamma subunit of AMPK gene (Prkag3) was also observed to be significantly differentially expressed (1.71fold, P-value $<0.05)$ though the expression was observed to be minimal compared to other significant differential mTOR-related genes. The activity of AMPK, precisely controlled by the ratio of AMP to adenosine triphosphate (ATP), reflects the cell energy status [43].

Among the genes that encode for downstream effectors of mTOR, only ribosomal protein S6 (Rps6) was significantly differentially expressed $(1.89$-fold, P-value $<0.05)$ in CL47[1] relative to the CL160[6]. The interactions among the upstream regulators, mTOR, and the downstream effectors are indicated in Figure 1. Although mTOR was not significantly expressed in this study, a gene that could be linked to its presence, known as Telo2, was upregulated by 2.44 -fold (P-value $<0.05$ ). This gene encodes telomere maintenance 2 (TEL2), which is responsible for mTOR stabilisation and maturation $[65,66]$. However, the mechanism by which TEL2 stabilizes mTOR remains poorly understood $[65,66]$.

\section{The relationship among $\mathrm{p} 110 \delta$ expression and specific} productivity, cell growth, and cell size

To investigate whether Pik3cd mRNA levels in the high and low producers are predictive of p110 $\delta$ expression, western blot analysis was performed on samples harvested from the mid-exponential phase (day three) of the batch cultures. Figure $5 \mathrm{a}$ shows the expression of the p110 subunit in GS-CHO cell lines with different $q_{p}$ levels ranging from 18 to $40 \mathrm{pg} / \mathrm{cell} /$ day. $(\mathrm{CL} 47[1]=50.54 \mathrm{pcd}$; CL76[2] = 47.23 pcd; CL150[3] = 38.73 pcd; CL164[4] = 21.23 pcd; CL38[5] = 18.34 pcd and CL160[6] = 2.91 pcd). The molecular characteristics of these cell lines have been extensively studied previously [67]. The integrated density values (IDV) corresponding to the band intensities were measured. Pearson correlation coefficient analysis was performed to determine the relationship between p110 $\delta$ subunit expression and the $q_{p}$ levels. The analysis revealed that the expression of the $\mathrm{p} 110 \delta$ subunit correlated with the overall $q_{p}(\rho=0.83, \mathrm{P}$-value $<0.05$; Figure $5 \mathrm{~b})$. This demonstrates the possibility that the $110 \delta$ subunit could be a potential marker describing $q_{p}$. Previous studies have demonstrated that PI3K overexpression could influence cell growth and proliferation [68-70]. Thus, we attempted to correlate expression of the p110 $\delta$ subunit with cell size and CVCT. A Pearson correlation coefficient analysis indicated that neither cell size nor CVCT (data not shown) correlated with the expression of the p110 $\delta$ subunit (P-value > 0.05).

\section{Discussion}

Since Dreesen and Fussenegger [46] recently showed that overexpression of mTOR in a $\mathrm{CHO}$ cell line significantly improved recombinant antibody production, we decided to investigate expression of members of the mTOR signalling in a panel of $\mathrm{CHO}$ cell lines with different levels of productivity. In order to address this question we used the

Table 2 The mTOR-related genes with at least a 1.5 -fold change in expression level (P-values $<0.05$ )

\begin{tabular}{|c|c|c|c|}
\hline Gene symbol & Description & Fold change & P-value \\
\hline Pik3cd & Phosphatidylinositol 3-kinase catalytic delta polypeptide & $(+) 71.33$ & 0.02 \\
\hline Pik3cg & Phosphoinositide-3-kinase, catalytic, gamma polypeptide & $(+) 6.59$ & $<0.001$ \\
\hline Pld1 & Phospholipase D1 & $(+) 4.63$ & 0.02 \\
\hline Rragc & Ras-related GTP binding C & $(+) 3.08$ & 0.05 \\
\hline $\ln s 2$ & Insulin || & $(+) 3.06$ & 0.02 \\
\hline Telo2 & TEL2, telomere maintenance 2 , homolog (S. cerevisiae) & $(+) 2.44$ & 0.01 \\
\hline Rps6 & Ribosomal protein $\mathrm{S} 6$ & $(+) 1.89$ & 0.05 \\
\hline Prkab1 & Protein kinase, AMP-activated, beta 1 non-catalytic subunit & (+) 1.71 & 0.02 \\
\hline
\end{tabular}




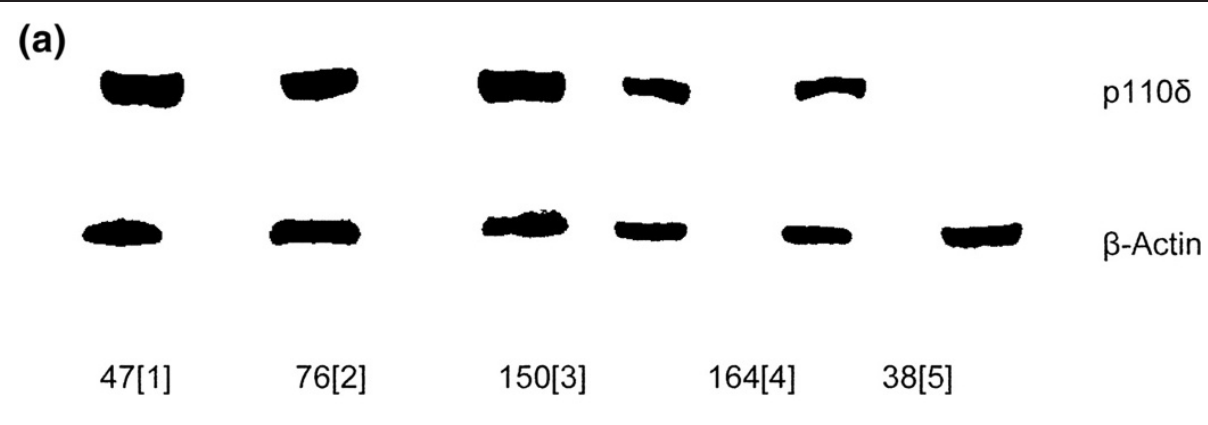

(b)

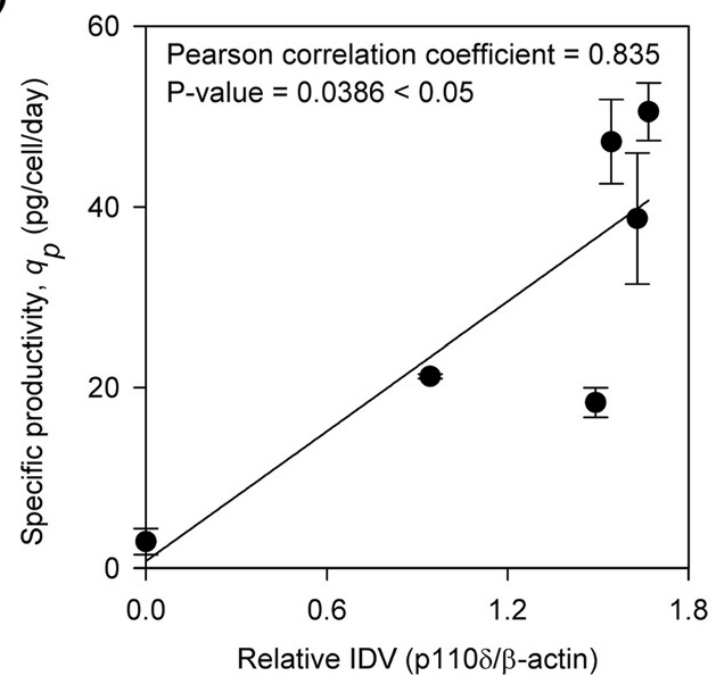

Figure 5 Comparison of $\mathrm{p} 110 \sigma$ subunit expressions between (a) six GS-CHO cell lines with different productivity levels at the mid-exponential phase of batch culture and (b) the correlation between $\mathbf{p} 110 \sigma$ expression and $\boldsymbol{q}_{\boldsymbol{p}}$. Error bars symbolize the standard deviation as calculated between three biological replicates.

mTOR signalling PCR array for mouse due to the unavailability of the hamster array at that time. Given that the mTOR signalling pathway is conserved from yeast to mammals [71], we used mouse sequences instead of hamster to quantify the levels of mTOR-related gene expressions in this study. Previous transcriptomic studies which relied on cross-hybridization to mouse DNA microarrays have showed considerable success [72] and in general, results from alignment to both mouse and rat reference genomes suggest that $\mathrm{CHO}$ genomic sequences are generally more similar to mouse genomic sequences [73]. Of the 84 mTOR-related genes present on the array only eight genes including, Pik3cd, Pik3cg, Ins2, Pld1, Rragc, Prkag3, Rps6 and Telo2 were identified as significantly ( $\mathrm{p}<0.05)$ upregulated in CL47[1] in comparison to CL160 [6]. This panel of candidate genes could potentially determine high specific productivity in $\mathrm{CHO}$ cell lines. Two of the genes that were highly expressed, Pik3cd and Pik3cg, encode for $\mathrm{p} 110 \delta$ and $\mathrm{p} 110 \gamma$ polypeptides, respectively and are also present on the SA Biosciences hamster mTOR signalling PCR array (PAJJ-098Z). These polypeptides differ at the regulatory subunit structure that is responsible for mediating $\mathrm{p} 110 \delta$ and $\mathrm{p} 110 \mathrm{\gamma}$ recruitment to the receptors of interest. The presence of $\mathrm{p} 110 \delta$ as a regulatory subunit facilitates the binding of p110y to the G protein beta subunit-like (GBl) in response to a stimulated G-protein couple receptor (GPCR). The recruitment of the p110 $\delta$ subunit to the activated receptor tyrosine kinase (RTK) is, however, mediated by a different regulatory subunit, p85, in response to various extracellular growth factors and insulin signals $[35,74,75]$. Hence, the different receptors as targets imply that upregulation of pik3cd gene could be independent of pik3cg (and vice versa), even though these polypeptides share a common role in catalysing phosphorylation of the inositol ring at the D3 position of their downstream effectors, the phosphoinositides.

Although the effects of $\mathrm{p} 110 \delta$ in recombinant protein production have yet to be clarified, its associations with growth are better understood. The effects of p110 $\delta$ overexpression have been correlated to cell growth and cell size in Drosophila, where expansion of the wing blade was due to an increase in cell number and cell size. A reverse effect on cell growth was observed in p1108-deficient cells 
[68]. The real cause, which affects the lack of correlation between the CVCT and cell size with p110 expression, is not clear. The correlation could be weakened by the presence of the medium producer cell line in which other signalling pathways could have compensated for the lack of effects of p110 $\delta$ expression on cell growth. However, this expression effect is more profound when only two extremes (high and low producers) were considered. CL160 [6] has a smaller cell size (data not shown) than CL47[1], and this could partly result from the defective p110 $\mathrm{ex}-$ pression in CL160[6] [51,68]. There has been some studies published which examined the use of genetic control of the cell cycle to increase $q_{p}$. However, these studies cannot confirm that the production of recombinant protein is related to any specific phase of the cell cycle. However, the increase in $q_{p}$ can be related to cell size rather than the cell cycle phase [17]. This has been shown previously by $\mathrm{Bi}$ et al. [30] in a cytostatic system utilising inducible expression of $\mathrm{p}_{21} 1^{\mathrm{CIP} 1}$ to arrest $\mathrm{CHO}$ cells where a fourfold increase of $q_{p}$ was obtained concomitant to a fourfold increase in cell volume. Regardless of cell cycle phase, the cell size could also be controlled by p $110 \delta$ expression through protein synthesis, a mechanism that is important for cell growth and proliferation. As cells have to retain a constant cell size during proliferation, a tight coordination between cell growth and cell cycle progression is essential for maintaining cell size and these processes are controlled by p110 $\delta$ expression as the upstream regulator of mTOR signalling pathway [33,76,77].

While the regulation of p110 $\delta$ activity is related to cell growth, the activity of p110y involves the regulation of cell survival [78-80]. An increased resistance to cell death was also observed as a result of the simultaneous inhibition of $\mathrm{p} 53$ and activation of nuclear factor $\mathrm{kB}$ (NF-kB) signalling pathways by Akt phosphorylation following the overexpression of the p110y subunit in human cell lines [80].

In addition, Prkag3, Pld1, and Rragc genes were also significantly expressed in CL47 [1], and these could be related to high specific productivity. These genes encode AMPK, PLD, and Ras-related GTP-binding protein C, which represent upstream regulators of mTOR. The altered expression of these genes may implicate the expression of the Rsp6 gene, which encodes the S6 protein. The S6 protein regulates the translation of ribosomal protein, elongation factor, and polyA-binding protein, that could lead to ribosome biogenesis [81-83]. This suggests that the improved specific productivity in CL47 [1] could be due to the altered expression of the Rsp6 gene. Our results were supported by a study conducted by $\mathrm{Bi}$ et al. [30]. A significant increase in $\mathrm{mAb}$ titre was shown to correlate with higher S6 protein expression in an isopropyl- $\beta$-d-thiogalactoside (IPTG)-induced $\mathrm{p} 21^{\mathrm{cip}}$ arrested CHO cell line [30].
We also found altered expression of the Ins 2 gene in the CL47[1] cell line; this gene is not commonly expressed in non-pancreatic $\beta$ cells. It is known that all cells contain an insulin gene, but its expression can vary in different cell types. The expression of Ins 2 could be controlled at the transcriptional level. It was shown previously by Kuroda et al. [84] that the Ins 2 gene was fully methylated and becomes demethylated as the cells differentiate into insulin-expressing cells in vitro [84]. If $\mathrm{CHO}$ cells could produce insulin, this would make the cells less dependent on exogenous insulin, which is certainly an advantageous trait in recombinant protein production.

\section{Conclusion}

This study provides a better understanding of the role of the mTOR signalling pathway in GS-CHO cell lines and identifies the importance of this pathway in recombinant protein production. We also highlight the presence of the $\mathrm{p} 110 \delta$ subunit of PI3K as a potential key regulator in productivity that may represent a future target for cellengineering strategies for enhancing productivity. Cellengineering approaches such as overexpression and/or gene silencing could be used to verify the roles of $\mathrm{p} 110 \delta$ and $\mathrm{p} 110 \mathrm{\gamma}$ in cellular functions that may be involved in recombinant protein production.

\section{Competing interests}

The authors declare no competing interests.

\section{Authors' contribution}

RE carried out the molecular genetic and cell culture studies, and participated in the sequence alignment. All authors wrote, edited and approved the manuscript.

\section{Acknowledgements}

The work was funded by grant from HEA, Ireland: PRTLI cycle 4- (Bio) Pharmaceutical and Pharmacological Sciences project and from Majlis Amanah Rakyat, MARA, Malaysia.

Received: 27 January 2014 Accepted: 5 February 2014

Published: 17 February 2014

\section{References}

1. Walsh G: Biopharmaceutical benchmarks. Nat Biotechnol 2000, 18(8):831-3.

2. Walsh G: Biopharmaceutical benchmarks. Nat Biotechnol 2010, 28(9):917-24.

3. Chu L, Robinson DK: Industrial choices for protein production by largescale cell culture. Curr Opin Biotechnol 2001, 12(2):180-187.

4. Seth G, Charaniya S, Wlaschin KF, Hu W-S: In pursuit of a super produceralternative paths to high producing recombinant mammalian cells. Curr Opin Biotechnol 2007, 18:8.

5. Derouazi M, Girard P, Van Tilborgh F, Iglesias K, Muller N, Bertschinger M, Wurm FM: Serum-free large-scale transient transfection of $\mathrm{CHO}$ cells. Biotechnol Bioeng 2004, 87(4):537-545.

6. Haldankar R, Li D, Saremi Z, Baikalov C, Deshpande R: Serum-free suspensin large-scale transient transfection of $\mathrm{CHO}$ cells in WAVE bioreactors. Mol Biotechnol 2006, 34(2):191-199.

7. Xing Z, Kenty BM, Li ZJ, Lee SS: Scale-up analysis for a CHO cell culture process in large-scale bioreactors. Biotechnol Bioeng 2009, 103(4):733-746.

8. Lucas BK, Giere LM, DeMarco RA, Shen A, Chisholm V, Crowley CW: Highlevel production of recombinant proteins in $\mathrm{CHO}$ cells using a dicistronic DHFR intron expression vector. Nucleic Acids Res 1996, 24(9):1774-1779. 
9. Pu H, Cashion LM, Kretschmer PJ, Liu Z: Rapid establishment of highproducing cell lines using dicistronic vectors with glutamine synthetase as the selection marker. Mol Biotechnol 1998, 10(1):17-25.

10. Hilal-Alnaqbi A, Hu A, Zhang Z, Al-Rubeai M: Growth, metabolic activity, and productivity of immobilized and freely suspended $\mathrm{CHO}$ cells in perfusion culture. Biotechnol Appl Biochem 2013, 60:436-445.

11. Kaneko Y, Sato R, Aoyagi H: Evaluation of Chinese hamster ovary cell stability during repeated batch culture for large-scale antibody production. J Biosci Bioeng 2010, 109(3):274-280.

12. Konstantinov KB, Tsai $Y$, Moles $D$, Matanguihan R: Control of long-term perfusion chinese hamster ovary cell culture by glucose auxostat. Biotechnol Prog 2008, 12(1):100-109.

13. Kou TC, Fan L, Ye ZY, Zhou Y, Liu XP, Zhao L, Tan WS: Process analysis of reduced specific productivity of TNFR-Fc in Chinese hamster ovary cells at high cell density. Process Biochem 2011, 46(7):1492-1499.

14. Gasser F, Mulsant P, Gillois M: Long-term multiplication of the Chinese hamster ovary $(\mathrm{CHO})$ cell line in a serum-free medium. In Vitro Cell Dev Biol Plant 1985, 21(10):588-592.

15. Haldankar R, Kopchick JJ, Ridgway D: Stable production of a human growth hormone antagonist from $\mathrm{CHO}$ cells adapted to serum, ÄêFree suspension culture. Biotechnol Prog 1999, 15(3):336-346.

16. Sinacore M, Charlebois T, Harrison S, Brennan S, Richards T, Hamilton M, Scott S, Brodeur S, Oakes P, Leonard M: CHO DUKX cell lineages preadapted to growth in serum-free suspension culture enable rapid development of cell culture processes for the manufacture of recombinant proteins. Biotechnol Bioeng 2000, 52(4):518-528.

17. Dinnis DM, James DC: Engineering mammalian cell factories for improved recombinant monoclonal antibody production: lessons from nature? Biotechnol Bioeng 2005, 91(2):180-189.

18. Page MJ, Sydenham MA: High level expression of the humanized monoclonal antibody CAMPATH-1H in chinese hamster ovary cells. Nat Biotech 1991, 9(1):64-68.

19. Wurm FM: Production of recombinant protein therapeutics in cultivated mammalian cells. Nat Biotechnol 2004, 22(11):1393-1398.

20. Chusainow J, Yang YS, Yeo JH, Toh PC, Asvadi P, Wong NS, Yap MG: A study of monoclonal antibody-producing $\mathrm{CHO}$ cell lines: what makes a stable high producer? Biotechnol Bioeng 2009, 102(4):1182-1196.

21. Fann $\mathrm{CH}$, Guarna MM, Kilburn DG, Piret JM: Relationship between recombinant activated protein $C$ secretion rates and mRNA levels in baby hamster kidney cells. Biotechnol Bioeng 1999, 63(4):464-472.

22. Gu MB, Todd P, Kompala DS: Metabolic burden in recombinant $\mathrm{CHO}$ cells: effect ofdhfr gene amplification andlacZ expression. Cytotechnology 1995, 18(3):159-166.

23. Jiang $Z$, Huang $Y$, Sharfstein ST: Regulation of recombinant monoclonal antibody production in chinese hamster ovary cells: a comparative study of gene copy number, mRNA level, and protein expression. Biotechnol Prog 2008, 22(1):313-318.

24. Kim SJ, Kim NS, Ryu CJ, Hong HJ, Lee GM: Characterization of chimeric antibody producing $\mathrm{CHO}$ cells in the course of dihydrofolate reductasemediated gene amplification and their stability in the absence of selective pressure. Biotechnol Bioeng 1998, 58(1):73-84.

25. Pendse GJ, Karkare S, Bailey JE: Effect of cloned gene dosage on cell growth and hepatitis $B$ surface antigen synthesis and secretion in recombinant CHO cells. Biotechnol Bioeng 1992, 40(1):119-129.

26. Kidane A, Guan Y, Evans P, Kaderbhai M, Kemp R: Comparison of heat flux in wild-type and genetically-engineered chinese hamster ovary cells. J Therm Anal Calorim 1997, 49(2):771-783.

27. Lloyd DR, Holmes P, Jackson LP, Emery AN, Al-Rubeai M: Relationship between cell size, cell cycle and specific recombinant protein productivity. Cytotechnology 2000, 34(1):59-70.

28. Carvalhal AV, Marcelino I, Carrondo MJT: Metabolic changes during cell growth inhibition by p27 overexpression. Appl Microbiol Biotechnol 2003, 63(2):164-173

29. Khoo SH, Al-Rubeai M: Detailed understanding of enhanced specific antibody productivity in NSO myeloma cells. Biotechnol Bioeng 2009, 102(1):188-199.

30. Bi JX, Shuttleworth J, Al-Rubeai M: Uncoupling of cell growth and proliferation results in enhancement of productivity in p21CIP1-arrested $\mathrm{CHO}$ cells. Biotechnol Bioeng 2004, 85(7):741-749.

31. Arsham AM, Neufeld TP: Thinking globally and acting locally with TOR Curr Opin Cell Biol 2006, 18(6):589-97.
32. Fingar DC, Richardson CJ, Tee AR, Cheatham L, Tsou C, Blenis J: mTOR controls cell cycle progression through its cell growth effectors S6K1 and 4E-BP1/eukaryotic translation initiation factor 4E. Mol Cell Biol 2004, 24(1):200-216

33. Ma XM, Blenis J: Molecular mechanisms of mTOR-mediated translationa control. Nat Rev Mol Cell Biol 2009, 10(5):307-18.

34. Polak P, Hall MN: mTOR and the control of whole body metabolism. Curr Opin Cell Biol 2009, 21(2):209-18.

35. Engelman JA, Luo J, Cantley LC: The evolution of phosphatidylinositol 3-kinases as regulators of growth and metabolism. Nat Rev Genet 2006, 7(8):606-19.

36. Sarbassov DD, Ali SM, Sabatini DM: Growing roles for the mTOR pathway. Curr Opin Cell Biol 2005, 17(6):596-603.

37. Shaw RJ, Cantley LC: Ras, $\mathrm{PI}(3) \mathrm{K}$ and mTOR signalling controls tumour cell growth. Nature 2006, 441(7092):424-30.

38. Proud CG: mTOR-mediated regulation of translation factors by amino acids. Biochem Biophys Res Commun 2004, 313(2):429-36.

39. Fang $Y$, Vilella-Bach M, Bachmann R, Flanigan A, Chen J: Phosphatidic acid-mediated mitogenic activation of mTOR signaling. Sci Signal 2001, 294(5548):1942.

40. Peng T, Golub TR, Sabatini DM: The immunosuppressant rapamycin mimics a starvation-like signal distinct from amino acid and glucose deprivation. Mol Cell Biol 2002, 22(15):5575-84.

41. Sancak Y, Peterson TR, Shaul YD, Lindquist RA, Thoreen CC, Bar-Peled L, Sabatini DM: The Rag GTPases bind raptor and mediate amino acid signaling to mTORC1. Sci Signal 2008, 320(5882):1496.

42. Christie GR, Hajduch E, Hundal HS, Proud CG, Taylor PM: Intracellular sensing of amino acids in xenopus laevis oocytes stimulates p70 S6 kinase in a target of rapamycin-dependent manner. J Biol Chem 2002, 277(12):9952-7.

43. Bolster DR, Crozier SJ, Kimball SR, Jefferson LS: AMP-activated protein kinase suppresses protein synthesis in rat skeletal muscle through down-regulated mammalian target of rapamycin (mTOR) signaling. J Biol Chem 2002, 277(27):23977-23980.

44. Chong WPK, Sim LC, Wong KTK, Yap MGS: Enhanced IFNY production in adenosine-treated CHOCells: a mechanistic study. Biotechnol Prog 2009, 25(3):866-873

45. Dennis PB, Jaeschke A, Saitoh M, Fowler B, Kozma SC, Thomas G: Mammalian TOR: a homeostatic ATP sensor. Science 2001, 294(5544):1102-5.

46. Dreesen IA, Fussenegger M: Ectopic expression of human mTOR increases viability, robustness, cell size, proliferation, and antibody production of chinese hamster ovary cells. Biotechnol Bioeng 2011, 108(4):853-66.

47. Browne SM, Al-Rubeai M: Analysis of an artificially selected GS-NSO variant with increased resistance to apoptosis. Biotechnol Bioeng 2011, 108(4):880-92.

48. O'Callaghan PM, McLeod J, Pybus LP, Lovelady CS, Wilkinson SJ, Racher AJ, Porter A, James DC: Cell line-specific control of recombinant monoclonal antibody production by $\mathrm{CHO}$ cells. Biotechnol Bioeng 2010, 106(6):938-951.

49. Calvisi DF, Wang C, Ho C, Ladu S, Lee SA, Mattu S, Destefanis G, Delogu S, Zimmermann A, Ericsson J: Increased lipogenesis, induced by AKTmTORC1-RPS6 signaling, promotes development of human hepatocellular carcinoma. Gastroenterol 2011, 140(3):1071-1083. e5.

50. Missiaglia E, Dalai I, Barbi S, Beghelli S, Falconi M, della Peruta M, Piemonti L, Capurso G, Di Florio A, delle Fave G: Pancreatic endocrine tumors: expression profiling evidences a role for AKT-mTOR pathway. J Clin Oncol 2010, 28(2):245-255.

51. Boller D, Schramm A, Doepfner KT, Shalaby T, von Bueren AO, Eggert A, Grotzer MA, Arcaro A: Targeting the phosphoinositide 3-kinase isoform p110 impairs growth and survival in neuroblastoma cells. Clin Cancer Res 2008, 14(4):1172-81.

52. Kang S, Bader AG, Vogt PK: Phosphatidylinositol 3-kinase mutations identified in human cancer are oncogenic. Proc Natl Acad Sci USA 2005, 102(3):802-807.

53. Toschi A, Lee E, Xu L, Garcia A, Gadir N, Foster DA: Regulation of mTORC1 and mTORC2 complex assembly by phosphatidic acid: competition with rapamycin. Mol Cell Biol 2009, 29(6):1411-1420.

54. Kim E, Goraksha-Hicks P, Li L, Neufeld TP, Guan KL: Regulation of TORC1 by Rag GTPases in nutrient response. Nat Cell Biol 2008, 10(8):935-945. 
55. Sancak Y, Bar-Peled L, Zoncu R, Markhard AL, Nada S, Sabatini DM: Ragulator-Rag complex targets mTORC1 to the lysosomal surface and is necessary for its activation by amino acids. Cell 2010, 141(2):290-303.

56. Holz MK, Ballif BA, Gygi SP, Blenis J: mTOR and S6K1 mediate assembly of the translation preinitiation complex through dynamic protein interchange and ordered phosphorylation events. Cell 2005, 123(4):569-80

57. Kimball SR, Shantz LM, Horetsky RL, Jefferson LS: Leucine regulates translation of specific mRNAs in L6 myoblasts through mTOR-mediated changes in availability of elF4E and phosphorylation of ribosomal protein S6. J Biol Chem 1999, 274(17):11647-11652.

58. Neshat MS, Mellinghoff IK, Tran C, Stiles B, Thomas G, Petersen R, Frost P, Gibbons JJ, Wu H, Sawyers CL: Enhanced sensitivity of PTEN-deficient tumors to inhibition of FRAP/mTOR. Proc Natl Acad Sci 2001, 98(18):10314-10319.

59. Sahin F, Kannangai R, Adegbola O, Wang J, Su G, Torbenson M: mTOR and P70 S6 kinase expression in primary liver neoplasms. Clin Cancer Res 2004, 10(24):8421-8425.

60. Hayward BE, Hussain A, Wilson RH, Lyons A, Woodcock V, Mclntosh B, Harris TJR: The cloning and nucleotide sequence of CDNA for an amplified glutamine synthetase gene from the Chinese hamster. Nucl Acids Res 1986, 14(2):999-1008.

61. Kalwy S, Rance J, Young R: Toward more efficient protein expression. Mol Biotechnol 2006, 34(2):151-156.

62. Livak KJ, Schmittgen TD: Analysis of relative gene expression data using real-time quantitative PCR and the 2- $\Delta \Delta C T$ method. Methods 2001, 25(4):402-408

63. Latres $E$, Amini AR, Amini AA, Griffiths J, Martin FJ, Wei $Y$, Lin $H C$ Yancopoulos GD, Glass DJ: Insulin-like growth factor-1 (IGF-1) inversely regulates atrophy-induced genes via the phosphatidylinositol 3-kinase/ $\mathrm{Akt} / \mathrm{mammalian}$ target of rapamycin (PI3K/Akt/mTOR) pathway. J Biol Chem 2005, 280(4):2737-2744

64. Sanchezmargalet V, Goldfine ID, Vlahos CJ, Sung CK: Role of phosphatidylinositol-3-kinase in insulin receptor signaling: studies with inhibitor, LY294002. Biochem Biophys Res Commun 1994, 204(2):446-452.

65. Takai $\mathrm{H}$, Wang $\mathrm{RC}$, Takai $\mathrm{KK}$, Yang $\mathrm{H}$, de Lange $\mathrm{T}$ : Tel2 regulates the stability of PI3K-related protein kinases. Cell 2007, 131(7):1248-1259.

66. Takai $H$, Xie $Y$, de Lange T, Pavletich NP: Tel2 structure and function in the Hsp90-dependent maturation of mTOR and ATR complexes. Genes Dev 2010, 24(18):2019-2030.

67. Edros RZ, McDonnell S, Al-Rubeai M: Using molecular markers to characterize productivity in chinese hamster ovary cell lines. PLoS One 2013, 8(10):e75935.

68. Leevers SJ, Weinkove D, MacDougall LK, Hafen E, Waterfield MD: The Drosophila phosphoinositide 3-kinase Dp110 promotes cell growth. EMBO J 1996, 15(23):6584-94

69. Luo J, McMullen JR, Sobkiw CL, Zhang L, Dorfman AL, Sherwood MC, Logsdon MN, Horner JW, DePinho RA, Izumo S: Class IA phosphoinositide 3-kinase regulates heart size and physiological cardiac hypertrophy. Mol Cell Biol 2005, 25(21):9491-9502

70. Shioi T, Kang PM, Douglas PS, Hampe J, Yballe CM, Lawitts J, Cantley LC, Izumo S: The conserved phosphoinositide 3-kinase pathway determines heart size in mice. EMBO J 2000, 19(11):2537-2548.

71. Huang S, Houghton PJ: Targeting mTOR signaling for cancer therapy. Curr Opin Pharmacol 2003, 3(4):371-377.

72. Yee JC, Wlaschin KF, Chuah SH, Nissom PM, Hu WS: Quality assessment of cross-species hybridization of $\mathrm{CHO}$ transcriptome on a mouse DNA oligo microarray. Biotechnol Bioeng 2008, 101:1359-1365.

73. Wlaschin KF, Nissom PM, Gatti Mde L, Ong PF, Arleen S, Tan KS, Rink A, Cham B, Wong K, Yap M, Hu WS: EST sequencing for gene discovery in Chinese hamster ovary cells. Biotechnol Bioeng 2005, 91:592-606.

74. Fry MJ: Structure, regulation and function of phosphoinositide 3-kinases. Biochim Biophys Acta 1994, 1226(3):237-68.

75. Wymann MP, Pirola L: Structure and function of phosphoinositide 3-kinases. Biochim Biophys Acta 1998, 1436(1-2):127-50.

76. Fingar DC, Blenis J: Target of rapamycin (TOR): an integrator of nutrient and growth factor signals and coordinator of cell growth and cell cycle progression. Oncogene 2004, 23(18):3151-71.

77. Fingar DC, Salama S, Tsou C, Harlow E, Blenis J: Mammalian cell size is controlled by mTOR and its downstream targets S6K1 and 4EBP1/elF4E. Genes Dev 2002, 16(12):1472-1487.
78. Brazzatti JA, Klingler-Hoffmann M, Haylock-Jacobs S, Harata-Lee Y, Niu M, Higgins MD, Kochetkova M, Hoffmann P, McColl SR: Differential roles for the p101 and p84 regulatory subunits of PI3Ky in tumor growth and metastasis. Oncogene 2012, 31(18):2350-61.

79. Dogra C, Changotra H, Wergedal JE, Kumar A: Regulation of phosphatidylinositol 3-kinase (PI3K)/Akt and nuclear factor-kappa B signaling pathways in dystrophin-deficient skeletal muscle in response to mechanical stretch. J Cell Physio/ 2006, 208(3):575-585.

80. Guo C, Gasparian AV, Zhuang Z, Bosykh DA, Komar AA, Gudkov AV, Gurova KV: 9-Aminoacridine-based anticancer drugs target the PI3K/AKT/mTOR, NF-kappaB and p53 pathways. Oncogene 2009, 28(8):1151-61.

81. Avni $D$, Biberman $Y$, Meyuhas $\mathrm{O}$ : The $5^{\prime}$ terminal oligopyrimidine tract confers translational control on TOP mRNAs in a cell type-and sequence context-dependent manner. Nucleic Acids Res 1997, 25(5):995-1001.

82. Jefferies $\mathrm{H}$, Reinhard C, Kozma S, Thomas G: Rapamycin selectively represses translation of the "polypyrimidine tract" mRNA family. Proc Nat Acad Sci 1994, 91(10):4441-4445.

83. Terada N, Patel HR, Takase K, Kohno K, Nairn AC, Gelfand EW: Rapamycin selectively inhibits translation of mRNAs encoding elongation factors and ribosomal proteins. Proc Natl Acad Sci 1994, 91(24):11477-11481.

84. Kuroda A, Rauch TA, Todorov I, Ku HT, Al-Abdullah IH, Kandeel F, Mullen Y, Pfeifer GP, Ferreri K: Insulin gene expression is regulated by DNA methylation. PLoS One 2009, 4(9):e6953.

doi:10.1186/1472-6750-14-15

Cite this article as: Edros et al:: The relationship between mTOR signalling pathway and recombinant antibody productivity in $\mathrm{CHO}$ cell lines. BMC Biotechnology 2014 14:15.

\section{Submit your next manuscript to BioMed Central and take full advantage of:}

- Convenient online submission

- Thorough peer review

- No space constraints or color figure charges

- Immediate publication on acceptance

- Inclusion in PubMed, CAS, Scopus and Google Scholar

- Research which is freely available for redistribution

Submit your manuscript at www.biomedcentral.com/submit
C) Biomed Central 